Pontifícia Universidade Católica $_{\text {do Rio daneiro }}$

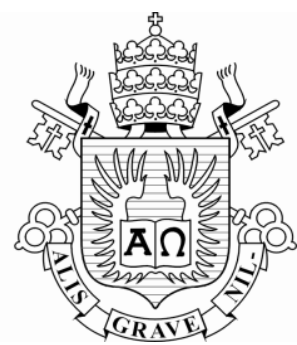

Carlos Monteiro Junior

\title{
A linguagem no Crátilo de Platão
}

\section{Dissertação de Mestrado}

Dissertação apresentada como requisito parcial para obtenção do grau de Mestre pelo Programa de Pósgraduação em Filosofia da PUC-Rio.

Orientador: Profạ. Maura Iglésias

Rio de Janeiro

Setembro de 2011 


\section{Pontifícia Universidade Católica DO RIO DE JANEIRO}

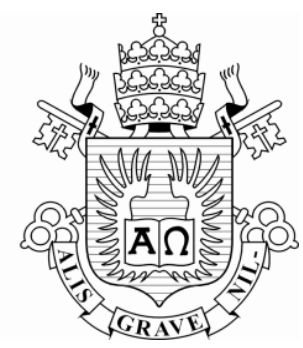

Carlos Monteiro Junior

\section{A linguagem no Crátilo de Platão}

Dissertação apresentada como requisito parcial para obtenção do grau de Mestre pelo Programa de Pósgraduação em Filosofia do Departamento de Filosofia do Centro de Teologia e Ciências Humanas da PUCRio. Aprovada pela Comissão Examinadora abaixo assinada.

Profa. Maura Iglésias

Orientadora

Departamento de Filosofia da PUC-Rio

Profa. Maria Inês Senra Anachoretta

Departamento de Filosofia da PUC-Rio

Prof. Fernando Décio Porto Muniz

Universidade Federal Fluminense - UFF

Profa. Denise Berruezo Portinari

Coordenadora Setorial do Centro de Teologia

e Ciências de Humanas - PUC-Rio

Rio de Janeiro, 12 de setembro de 2011. 
Todos os direitos reservados. É proibida a reprodução total ou parcial do trabalho sem autorização da universidade, da autora e do orientador.

\section{Carlos Monteiro Junior}

Atua na área de Filosofia, com ênfase em Filosofia Antiga. Gradou-se em Filosofia na UFRJ (Universidade Federal do Rio de Janeiro) em 2008. Atua, ainda, no ensino da Filosofia na Educação de Nível Médio e é pesquisador associado ao NUFA (Núcleo de Estudos de Filosofia Antiga).

Ficha Catalográfica

Monteiro Junior, Carlos

A linguagem no Crátilo de Platão / Carlos Monteiro Junior ; orientadora: Maura Iglesias. - 2011.

$95 \mathrm{f}$; ; $30 \mathrm{~cm}$

Dissertação (mestrado)-Pontifícia

Universidade Católica do Rio de Janeiro, Departamento de Filosofia, 2011.

Inclui bibliografia

1. Filosofia - Teses. 2. Crátilo. 3. Linguagem.

4. Sofística. 5. Naturalismo. 6. Convencionalismo. I. Iglesias, Maura. II. Pontifícia Universidade Católica do Rio de Janeiro. Departamento de Filosofia. III. Título.

CDD: 100 


\section{Agradecimentos}

Ao CNPq e à PUC-Rio, pelos auxílios concedidos, sem os quais este trabalho não poderia ter sido realizado.

Aos meus pais (Carlos e Simone) e outros familiares (Beto, meu irmão, e a Vó Teresa), pelo apoio, amor e carinho dado ao longo de toda minha vida.

Aos amigos de sempre (Fernando, Antonio, Miranda, João, Dersu, Mestre José Carlos e todos do grupo de Capoeira Angola N'Golo, entre outros), por estarem sempre ao meu lado nos momento difíceis e por compartilharem os momentos de alegria. Um agradecimento especial à Amanda, pelo amor e carinho.

À professora Maura Iglésias, pela orientação e pelas aulas, que contribuíram bastante no desenvolvimento deste trabalho e que fizeram aumentar o meu fascínio pela Filosofia Antiga, principalmente por Platão.

Aos professores Fernando Muniz e Maria Inês Anachoretta, pelo apoio e incentivo imprescindíveis para a concretização deste trabalho; aos dois agradeço também pelas leituras críticas e sugestões.

A todos os professores e alunos do NUFA, pelas discussões, trocas de informações, conversas no bar, desabafos e orientações. Um agradecimento especial aos colegas Antonio Queirós, Emerson Facão, Rafael Huguenin e Renato Matoso, pelas aulas de grego e outras colaborações. 


\section{Resumo}

Junior, Carlos Monteiro; Iglésias, Maura. A linguagem no Crátilo de Platão. Rio de Janeiro, 2011. 95p. Dissertação de Mestrado Departamento de Filosofia, Pontifícia Universidade Católica do Rio de Janeiro.

A dissertação A linguagem no Crátilo de Platão pretende, a partir da análise das teses apresentadas por Platão no diálogo Crátilo acerca da correção dos nomes e de suas respectivas refutações, realizar uma reflexão sobre modo como Platão irá direcionar as investigações filosóficas em relação à linguagem; e a presente dissertação pretende ainda ressaltar a importância de tal diálogo não só para o pensamento platônico, mas, também, para a preservação de algumas das primeiras discussões em torno da linguagem na história do pensamento humano. Esta dissertação é fruto de uma investigação mais geral que pretende analisar a relação, no contexto da filosofia grega, entre a filosofia e a sofística (retórica). Entre os comentadores é comum encontramos a ideia de que no século $\mathrm{V}$ e início do IV a.C, houve, por assim dizer, uma batalha, iniciada por Platão, entre a filosofia e a sofística, visando o monopólio intelectual na sociedade grega. E uma discussão capital neste embate entre a filosofia e a sofística diz respeito às funções, poderes e limites do logos. Então, ao analisar o Crátilo é possível perceber as particularidades platônicas em relação a tal discussão sobre a linguagem.

\section{Palavras-chave}

Crátilo; Linguagem; Sofística; Naturalismo; Convencionalismo. 


\section{Abstract}

Junior, Carlos Monteiro; Iglésias, Maura (Advisor). The language in Plato's Cratylus. Rio de Janeiro, 2011. 95p. MSc. Dissertation Departamento de Filosofia, Pontifícia Universidade Católica do Rio de Janeiro.

The dissertation The language in Plato's Cratylus intends, through the analysis of the theses presented by Plato in the Cratylus about the correctness of names and their refutations, make a reflection on how Plato will direct the philosophical investigations in relation to language; and also highlight the importance of such dialogue not only to Platonic thought, but also for the preservation of some of the first discussions about the language in the history of human thought. This dissertation is the result of a more general research that seeks to analyze the relationship in the context of Greek philosophy, between philosophy and sophistry (rhetoric). Among the commentators is common to find the idea that in the fifth century BC and early, there was, so to speak, a battle, begun by Plato, between philosophy and sophistry, seeking the intellectual monopoly of Greek society. And a discussion on this capital clash between philosophy and sophistry with regard to the functions, powers and limits of the logos. So, in analyzing the Cratylus is possible to identify particular with respect to such Platonic discussion of the language.

\section{Keywords}

Cratylus; Language; Sophistic; Naturalism; Conventionalism. 


\section{Sumário}

1. Introdução 8

2. Capítulo I - O convencionalismo de Hermógenes 23

3. Capítulo II - O naturalismo de Crátilo 65

4. Considerações finais 76

5. Referências bibliográficas 85 